University of Nebraska - Lincoln

DigitalCommons@University of Nebraska - Lincoln

1996

\title{
Climatic and Hydrologic Oscillations in the Owens Lake Basin and Adjacent Sierra Nevada, California
}

\author{
Larry Benson \\ University of Colorado at Boulder, great.basin666@gmail.com \\ James W. Burdett \\ U.S. Geological Survey \\ Michaele Kashgarian \\ Lawrence Livemore National Laboratory \\ Steve Lund \\ University of Southern California, slund@usc.edu \\ Fred Phillips \\ New Mexico Institute of Mining and Technology
}

See next page for additional authors

Follow this and additional works at: https://digitalcommons.unl.edu/usgsstaffpub

Part of the Geology Commons, Oceanography and Atmospheric Sciences and Meteorology Commons, Other Earth Sciences Commons, and the Other Environmental Sciences Commons

Benson, Larry; Burdett, James W.; Kashgarian, Michaele; Lund, Steve; Phillips, Fred; and Rye, Robert O., "Climatic and Hydrologic Oscillations in the Owens Lake Basin and Adjacent Sierra Nevada, California" (1996). USGS Staff -- Published Research. 798.

https://digitalcommons.unl.edu/usgsstaffpub/798

This Article is brought to you for free and open access by the US Geological Survey at DigitalCommons@University of Nebraska - Lincoln. It has been accepted for inclusion in USGS Staff -- Published Research by an authorized administrator of DigitalCommons@University of Nebraska - Lincoln. 


\section{Authors}

Larry Benson, James W. Burdett, Michaele Kashgarian, Steve Lund, Fred Phillips, and Robert O. Rye 


\section{Climatic and Hydrologic Oscillations in the Owens Lake Basin and Adjacent Sierra Nevada, California}

\section{Larry V. Benson, James W. Burdett, Michaele Kashgarian, Steve P. Lund, Fred M. Phillips, Robert O. Rye}

Oxygen isotope and total inorganic carbon values of cored sediments from the Owens Lake basin, California, indicate that Owens Lake overflowed most of the time between 52,500 and 12,500 carbon-14 $\left({ }^{14} \mathrm{C}\right)$ years before present (B.P.). Owens Lake desiccated during or after Heinrich event $\mathrm{H} 1$ and was hydrologically closed during Heinrich event H2. The magnetic susceptibility and organic carbon content of cored sediments indicate that about 19 Sierra Nevada glaciations occurred between 52,500 and 23,500 ${ }^{14} \mathrm{C}$ years B.P. Most of the glacial advances were accompanied by decreases in the amount of discharge reaching Owens Lake. Comparison of the timing of glaciation with the lithic record of North Atlantic core V23-81 indicates that the number of mountain glacial cycles and the number of North Atlantic lithic events were about equal between 39,000 and $23,500{ }^{14} \mathrm{C}$ years B.P.

Evidence of rapid oscillations in air and sea surface temperatures during the last glacial period have been recognized in ice cores from Greenland (1) and sediment cores from the North Atlantic $(2,3)$. Layers of lithic fragments rich in carbonate debris (Heinrich layers) have been found in sediment cores from the temperate North Atlantic and ap-

L. V. Benson, U.S. Geological Survey, 3215 Marine Street, Boulder, CO 80303, USA.

J. W. Burdett and R. O. Rye, U.S. Geological Survey, MS 963, Denver Federal Center, Lakewood, CO 80225, USA.

M. Kashgarian, Lawrence Livermore National Laboratory, Post Office Box 808, L-397, Livermore, CA 94550, USA.

S. P. Lund, Department of Earth Sciences, University of Southern California, Los Angeles, CA 90089, USA.

F. M. Phillips, Department of Earth and Environmental

Science, New Mexico Institute of Mining and Technology,

Socorro, NM 87801, USA. pear to be linked to the dynamics of the Laurentide Ice Sheet and other Northern Hemisphere ice sheets by the discharge of icebergs into the North Atlantic (3-5). The last four Heinrich events occurred at the end of progressive decreases in sea surface and air temperatures (Dansgaard-Oeschger cycles) and were followed by rapid warmings.

Several authors have attempted to link proxy records of climate change from other areas of the world to Dansgaard-Oeschger cycles and Heinrich events (6). In particular, it has been suggested that alpine glaciers in the Rocky Mountains advanced to their terminal areas up to several thousand years before a Heinrich event and retreated soon thereafter (7). However, limitations in chronology and sampling resolution have made it difficult to demonstrate that North Atlantic climatic oscillations were synchronous with climatic and hydrologic oscillations in other regions. Here we present continuous, well-dated, high-resolution proxy records of climate change in the Owens Lake basin and compare them with the North Atlantic lithic record documented in core V23-81 (8).

Owens Lake is located in the Great Basin of the western United States between the central Sierra Nevada and InyoWhite mountain ranges (Fig. 1). Coolseason orographic precipitation in the $\mathrm{Si}$ erra Nevada, mostly from North Pacific sources, supplies $>99 \%$ of the runoff reaching Owens basin (9).

Sediment cores OL90-1 (length, 32.75 $\mathrm{m})$ and OL90-2 $(28.20 \mathrm{~m})$ were obtained from the Owens Lake basin in 1990 (Fig. 1) (10). Age control for OL90-2 was based on 26 accelerator mass spectrometry (AMS) ${ }^{14} \mathrm{C}$ determinations made on the total organic carbon (TOC) fraction of the cored sediment (Fig. 2) (11). Age control for OL90-1 was obtained by matching 30 magnetic susceptibility $(\chi)$ features common to both cores. The OL90-2 ${ }^{14} \mathrm{C}$ age-depth polynomial was then applied to OL90-1. A continuous set of sediment samples, 5 to 6 $\mathrm{cm}$ in length, was taken from the two cores. Total carbon (TC), total inorganic carbon (TIC), and $\delta^{18} \mathrm{O}$ values were determined on each sample (12).

To determine if abrupt changes in climate affected the hydrologic balance of the Owens Lake basin, we examined the $\delta^{18} \mathrm{O}$ and TIC records (Fig. 3). The $\delta^{18} \mathrm{O}$ value (13) of a lake represents a balance between amounts and $\delta^{18} \mathrm{O}$ values of water input to and lost from a lake. When Owens Lake 
overflowed, $\delta^{18} \mathrm{O}$ was primarily a function of the outflow:inflow ratio. When the residence time of water in the Owens Lake basin approached zero, the $\delta^{18} \mathrm{O}$ of Owens Lake approached the $\delta^{18} \mathrm{O}$ value of inflow (calcite precipitated from a $15^{\circ} \mathrm{C}$ lake in which the outflow:inflow ratio approaches unity would have a $\delta^{18} \mathrm{O}$ value of $\sim 15$ per mil). Under steady-state conditions, the $\delta^{18} \mathrm{O}$ value of a hydrologically closed Great Basin lake would be highly enriched (calcite precipitated from a $15^{\circ} \mathrm{C}$ lake would have an $\delta^{18} \mathrm{O}$ value of $\sim 30$ per mil) (14).

Between 52,500 and 15,500 years before present (B.P.), $\delta^{18} \mathrm{O}$ values determined on the TIC fraction of Owens Lake sediment

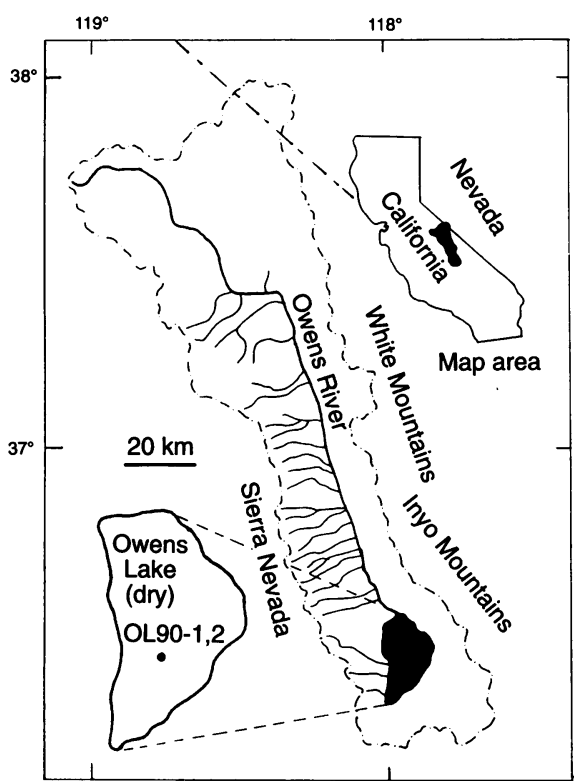

Fig. 1. Location map of the Owens Lake basin (dash-dotted line). Cores OL90-1 and -2 were taken within $200 \mathrm{~m}$ of each other.

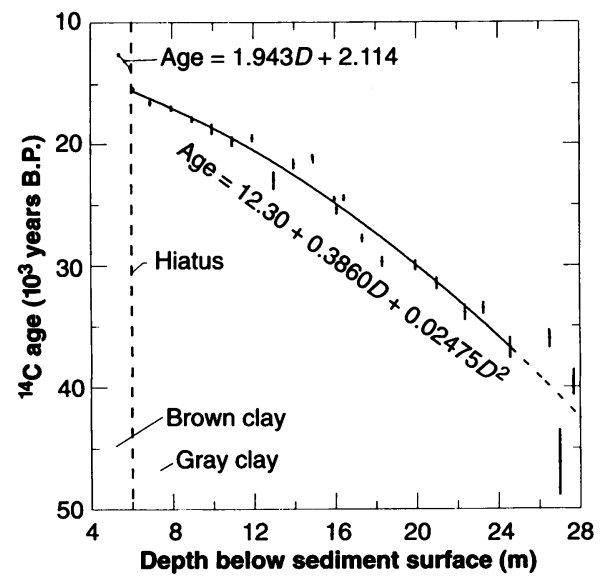

Fig. 2. $\mathrm{AMS}{ }^{14} \mathrm{C}$ age control for core OL9O-2. The ${ }^{14} \mathrm{C}$ age polynomial was not fit to ${ }^{14} \mathrm{C}$ ages of samples from depths $D>25 \mathrm{~m}$. A hiatus in the sediment record (dashed line) occurs at a depth of $6 \mathrm{~m}$. Ages have not been calibrated and are reported in ${ }^{14} \mathrm{C}$ years B.P. are generally low ( $<22$ per mil) (Fig. 3), indicating that Owens Lake overflowed most of this time (15). Isotopic values are relatively low between 40,000 and 30,000 years B.P., reflecting a climate that was extremely wet (low values also occur at 28,500 and 26,500 years B.P.). Before and after the interval characterized by extremes in $\delta^{18} \mathrm{O}$ minima, $\delta^{18} \mathrm{O}$ values reflect drier climates: For example, between 52,500 and 40,000 years B.P. there are several $\delta^{18} \mathrm{O}$ maxima that denote brief periods of intermittent closure $\left(\mathrm{C}_{1}\right.$ to $\left.\mathrm{C}_{8}\right)$. Owens Lake receded below the elevation of the core site and may have desiccated between $<15,500$ and 13,700 years B.P. (16). An abrupt decrease in $\delta^{18} \mathrm{O}$ at 13,300 years B.P. culminated in extremely low $\delta^{18} \mathrm{O}$ values at 13,000 years B.P., indicating a profound increase in wetness.

Chemical weathering of granitic Sierran rocks results in an Owens River composition dominated by $\mathrm{Na}, \mathrm{Ca}$, and $\mathrm{HCO}_{3}^{-}$(9). When Owens Lake was closed, all dissolved $\mathrm{Ca}$ (and an equal amount of $\mathrm{CO}_{3}{ }^{2-}$ ) entering Owens Lake precipitated as $\mathrm{CaCO}_{3}$. During overflow, some $\mathrm{Ca}$ and $\mathrm{HCO}_{3}{ }^{-}$ were lost from the basin; the greater the outflow:inflow ratio, the greater the loss of Ca. If influx of detrital silicates remained constant, increases in the fraction of $\mathrm{CaCO}_{3}$ (TIC) should have paralleled increases in $\delta^{18} \mathrm{O}$. Thus, comparison of TIC and $\delta^{18} \mathrm{O}$ records should allow us to determine times of uneven accumulation of detrital silicates.

First-order trends in $\mathrm{TIC}$ and $\delta^{18} \mathrm{O}$ parallel each other between 40,000 and 26,000 years B.P., but only a few TIC and $\delta^{18} \mathrm{O}$ maxima are coeval. Between 52,500 to 40,000 and 26,000 to 15,500 years B.P. variations in TIC and $\delta^{18} \mathrm{O}$ are not synchronous, and the percentage of TIC is typically low, indicating that detrital sediments have obscured the TIC signal (Fig. 3). A combination of scanning electron microscopy, $x$-ray diffraction, and grain-size data indicates that the detrital material is rock flour (fine silt) mainly transported to the Owens basin by glacial meltwater (17).

Magnetic susceptibility $(\chi)$ provides evidence for the timing of glaciation. The $\chi$ of Owens Lake sediment derives from the postdepositional alteration of detrital ironbearing minerals (for example, magnetite and biotite) to greigite $\left(\mathrm{Fe}_{3} \mathrm{~S}_{4}\right)$ in anoxic

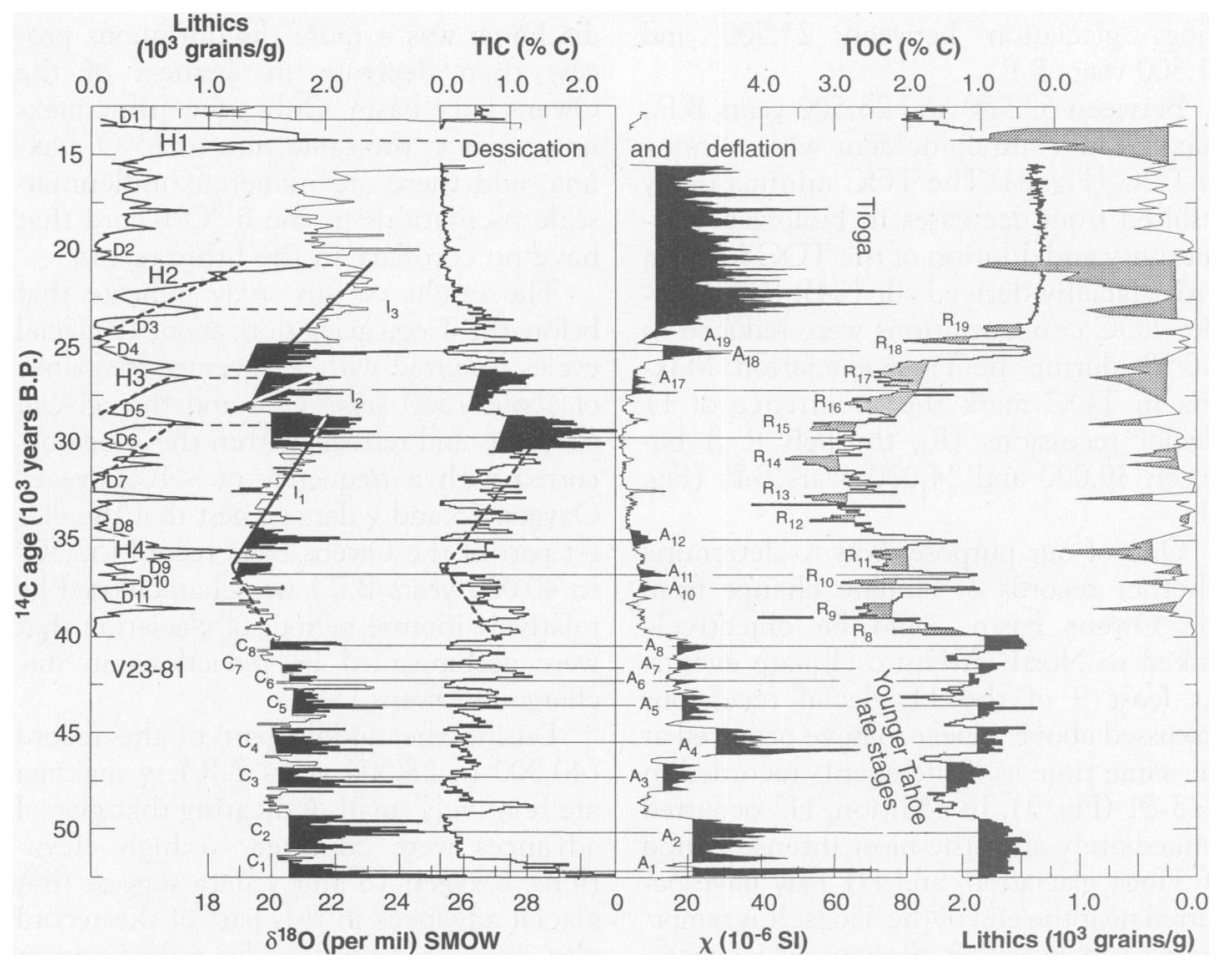

Fig. 3. The $\delta^{18} \mathrm{O}, \mathrm{TIC}, \mathrm{TOC}$, and $\chi$ records from cores OL90-1 and -2 compared with the lithic record from North Atlantic core V23-81 for the period 52,500 to 12,500 years B.P. Greenland DansgaardOeschger $(D)$ warm events and Heinrich $(H)$ events are indicated. Selected maxima in $\delta^{18} \mathrm{O}, \mathrm{TIC}, \chi$, and minima in TOC are shown in black; maxima in TOC and lithics (from V23-81) are indicated in gray. Lithics are measured in number of grains $>150 \mu \mathrm{m}$ in size per gram of sediment. Trends in increasing $\delta^{18} \mathrm{O}$ (decreases in wetness of the Owens Lake basin) are indicated by lines $I_{1}$ to $I_{3}$; Sierran glacial advances (peaks in $X$ ) are labeled $A_{1}$ to $A_{19}$; Sierran glacial recessions (peaks in TOC) between 39,000 and 24,000 ${ }^{14} \mathrm{C}$ years B.P. are labeled $R_{8}$ to $R_{19}$. Periods of hydrologic closure of Owens Lake before 40,000 years B.P. are labeled $C_{1}$ to $C_{8}$. Correlations among the OL90-1 and -2 records are indicated by thin solid lines. Dashed lines indicate possible correlations between lake size minima and lithic events. 
pore waters of Owens Lake (18); $\chi$, therefore, should act as an indicator of the intensity of glacial erosion in the central Sierra Nevada. New cosmogenic ${ }^{36} \mathrm{Cl}$ age estimates of Sierra Nevada moraines (19), together with other age estimates of Tioga glaciations $(20,21)$, demonstrate that maxima in $\chi$ occur during advances of Sierran glaciers.

The oldest series of $\chi$ events (between 52,500 and 40,000 years B.P.) may indicate late-stage advances of the Younger Tahoe glaciation $(21,22)$. The eight oldest glacial advances $\left(A_{1}\right.$ to $\left.A_{8}\right)$ occurred when relatively heavy $\delta^{18} \mathrm{O}$ values indicate that the lake was intermittently closed $\left(\mathrm{C}_{1}\right.$ to $\left.\mathrm{C}_{8}\right)$, suggesting that the climate was cold and relatively dry (Fig. 3). Between 40,000 and 23,500 years B.P., Owens Lake also experienced closure during glacial advances $A_{10}$ to $A_{12}, A_{17}$, and $A_{18}$. The Tioga glaciation also occurred during a relatively dry period $(23,500$ to 15,500 years B.P.). There are moderate peaks in $\chi$ between 40,000 and 27,500 years B.P. that indicate the advance of an as-yet-unnamed series of minor glaciers during a relatively wet interval (23). The moraines resulting from these minor glacial advances were probably overridden during subsequent intense periods of early Tioga glaciation between 23,500 and 21,500 years B.P.

Between 52,500 and 23,500 years B.P., maxima in $\chi$ are coincident with minima in TOC (Fig. 3). The TOC minima likely resulted from decreases in biological productivity and dilution of the TOC fraction with glacially derived silt (24). For example, TOC concentrations were reduced to $<0.3 \%$ during the Tioga glaciation. Maxima in TOC mark the occurrence of 11 glacial recessions $\left(R_{9}\right.$ through $\left.R_{19}\right)$ between 39,000 and 24,000 years B.P. (Fig. 3).

One of our purposes was to determine whether records of climate change from the Owens basin could be objectively linked to North Atlantic climate events. At least 9 of the 11 glacial recessions discussed above appear to have occurred at the same time as lithic events recorded in V23-81 (Fig. 3). In addition, $\mathrm{H} 2$ occurred immediately after the most intense period of Tioga glaciation, and H1 may have occurred near the end of the Tioga. It is tempting to conclude that Sierran glacial recessions were coeval with periods of accelerated iceberg discharge to the North Atlantic; however, ${ }^{14} \mathrm{C}$ age controls for OL90-2 (Fig. 2 ) and V23-81 do not permit this conclusion (25).

What can be said is that the number of advances and retreats of Sierran glaciers is almost identical to the number of iceberg discharge events. Air temperature strongly affects the size of alpine glaciers. Lithic and foraminiferal records from V23-81 indicate that periods of increased iceberg discharge occurred near the ends of cooling cycles (5). It is, therefore, plausible to suggest that variability in air temperature over the Northern Hemisphere may have linked Sierran glacier cycles with iceberg discharge cycles in the North Atlantic. Whether different regions in the Northern Hemisphere experienced synchronous changes in air temperature remains an unanswered question.

A comparison of the Owens Lake hydrologic-balance proxy $\left(\delta^{18} \mathrm{O}\right)$ with the North Atlantic lithic record does not indicate a high degree of correlation (Fig. 3) (26). A dry period occurred during or after $\mathrm{H} 1$, and the Owens Lake basin was relatively dry during $\mathrm{H} 2$. Between 37,000 and 21,000 years B.P., there are three intervals $\left(I_{1}=36,500\right.$ to 28,$500 ; I_{2}=28,000$ to 26,500; and $I_{3}=25,000$ to 20,500 years B.P.) where $\delta^{18} \mathrm{O}$ values increase in a more or less regular manner, indicating progressive decreases in the frequencies and amounts of overflow. Increases in lithic deposition in the North Atlantic paralleled $\delta^{18} \mathrm{O}$ increases during $\mathrm{I}_{1}, \mathrm{I}_{2}$, and the last half of $\mathrm{I}_{3}$, but increase in iceberg discharge was a more discontinuous process than decrease in wetness of the Owens Lake basin. Only a few lithic maxima occur at the same time as $\delta^{18} \mathrm{O}$ maxima, and there are numerous millennialscale oscillations in the $\delta^{18} \mathrm{O}$ record that have no corollary in the lithic record.

The results of this study indicate that before the Tioga glaciation, about 19 glacial cycles occurred with an average frequency of about 1500 years (27) and that glacial advances and retreats within the Tioga occurred with a frequency of $<1000$ years. Oxygen-18 and $\chi$ data suggest that the oldest part of the Owens Lake record $(52,500$ to 40,000 years B.P.) was characterized by relatively intense periods of glaciation that were accompanied by reductions in discharge to Owens Lake.

During the middle part of the record ( 40,000 to 28,000 years B.P.), $x$ maxima are relatively small, indicating that glacial advances were confined to high elevations. Oxygen-18 and $\chi$ data suggest that glacial advances in this part of the record also were accompanied by reductions in discharge to Owens Lake. The Tioga glaciation, which occurred during the most recent part of the record $(28,000$ to 15,500 years B.P.), was terminated by a severe drought that occurred during or immediately after H1. Comparison of the timing of glaciation with the lithic record of North Atlantic core V23-81 indicates that the number of mountain glacial cycles and the number of North Atlantic lithic events were about equal between 39,000 and 24,000 years B.P.

\section{REFERENCES AND NOTES}

1. W. Dansgaard et al., Nature 364, 218 (1993); P. M. Grootes et al., ibid. 366, 552 (1993); K. C. Taylor et al. , ibid. 361, 432 (1993).

2. W. F. Ruddiman, Geol. Soc. Am. Bull. 88,1813 (1977); H. Heinrich, Quat. Res. 29, 143 (1988).

3. G. Bond et al., Nature 360, 245 (1992); J. T. Andrews and K. Tedesco, Geology 20, 1087 (1992); J. T. Andrews et al., Can. J. Earth Sci. 31, 90 (1993).

4. W. S. Broecker et al., Clim. Dyn. 6, 265 (1992); W. S. Broecker, Nature 372, 421 (1994); J. A. Dowdeswell et al., Geology 23, 301 (1995).

5. G. C. Bond and R. Lotti, Science 267, 1005 (1995).

6. B. D. Allen and R. Y. Anderson, ibid. 260, 1920 (1993); E. C. Grimm, G. L. Jacobson Jr., W. A. Watts, B. C. S. Hansen, K. A. Maasch, ibid. 261, 198 (1993); F. M. Phillips et al., Geology 22, 1114 (1994); T. V. Lowell et al. , Science 269, 1541 (1995); S. C. Porter and A. Zhisheng, Nature 375, 305 (1995); R. J. Behl and J. P. Kennett, ibid. 379, 243 (1996).

7. P. U. Clark and P. J. Bartlein, Geology 23, 483 (1995).

8. Lithic percentages for core V23-81 were provided by G. Bond, Lamont Doherty Geological Observatory.

9. K. J. Hollett et al., U.S. Geol. Sun. Water Supply Pap. 2370 (1991). Thermal springs that discharge into the Owens River by way of Hot Creek contain much more carbonate and much less calcium than other surface-water systems [M. L. Sorey, J. Geophys. Res. 90, 11219 (1985)]. However, thermal water discharged into the Owens River has historically contributed $<1 \%$ of the calcium reaching Owens Lake; therefore, a change in the activity of these thermal springs would have little influence on the amount of TIC deposited in Owens Lake.

10. Sediments from OL90-1 and -2 are mostly fine silts made up of quartz, feldspar, and biotite fragments. Some authigenic calcite is also present.

11. The AMS ${ }^{14} \mathrm{C}$ dates were determined at the Lawrence Livermore National Laboratory Center for Accelerator Mass Spectrometry; before analysis, all samples were pre-treated with dilute $\mathrm{HCl}$ to remove inorganic carbon.

12. Each sample (which integrates $\sim 75$ years of record) was repeatedly suspended in $40 \mathrm{ml}$ of water and centrifuged, and the supernatant was decanted until its conductivity was less than three times that of tap water. The samples were then freeze-dried and homogenized. Magnetic susceptibility was measured every $2 \mathrm{~cm}$ with the use of a whole-core measurement sensor. The Inyo-White Mountains contain dolomite. If this dolomite was transported to Owens Lake, the measured $T I C$ and $\delta^{18} \mathrm{O}$ values would not be entirely representative of Owens Lake water; however, $x$-ray diffraction of several OL90-2 samples failed to indicate the presence of dolomite.

13. All $\delta^{18} \mathrm{O}$ values are reported relative to the Vienna standard mean ocean water (VSMOW) standard.

14. Today the mean value of precipitation falling in the central Sierra Nevada is $\sim-14.5$ per mil [L. V. Benson, Limnol. Oceanogr. 39, 344 (1994)], and the $\delta^{18} \mathrm{O}$ value of water evaporated from Pyramid Lake ( $\sim 350 \mathrm{~km}$ north of the Owens basin) is $\sim-14$ per mil (_and J. W. C. White, ibid., p. 1945). Thus, the steady-state $\delta^{18} \mathrm{O}$ value of a closed lake that receives water from the central Sierra Nevada should be -0.5 per mil. The ${ }^{18} \mathrm{O}$ fractionation factor between calcite and water is $\sim 30.5$ at $15^{\circ} \mathrm{C}$ [J. R. O'Neil et al., J. Chem. Phys. 51, 5547 (1969)]; therefore, the $\delta^{18} \mathrm{O}$ value of calcite precipitated from a closed lake would be $\sim 30$ per mil. When a lake overflows, its $\delta^{18} \mathrm{O}$ value is primarily a function of the outflow:inflow ratio; an increase in this ratio causes a decrease in the $\delta^{18} \mathrm{O}$ value of lake water. When this ratio approaches unity, the $\delta^{18} \mathrm{O}$ value of lake water approaches the $\delta^{18} \mathrm{O}$ value of precipitation $(\sim-14.5$ per mil). Calcite precipitated from this water would have a $\delta^{18} \mathrm{O}$ value of $\sim 16$ per mil. 
15. Overflow of Owens Lake occurs when wetness ex ceeds $\sim 2.4$ times the historical mean $[H$. S. Gale, U.S. Geol. Surv. Bull. 580-L, 251 (1914)].

16. Discontinuities in the depth-age distribution of OL.90-2 indicate a sediment hiatus between $\sim 15,500$ and $13,700{ }^{14} \mathrm{C}$ years B.P. Sediments at the base of the hiatus are characterized by features that indicate desiccation, including a 1- to 3-mmthick lag deposit of frosted quartz grains. Removal of sediments by wave reworking or deflation implies that the 15,500-year age represents a maximum estimate of the initiation of desiccation.

17. S. P. Lund, unpublished data.

18. The presence of greigite and the absence of magnetite in high- $x$ intervals were inferred from thermomagnetic measurements of magnetic mineral blocking temperatures.

19. F. M. Phillips et al., Science 274, 749 (1996).

20. R. I. Dorn et al., Quat. Res. 28, 38 (1987); M. I. Bursik and A. R. Gillespie, ibid. 39, 24 (1993); R. J. Poreda et al., Eos 76 (fall suppl.), 685 (1995).

21. F. M. Phillips et al., Science 248, 1529 (1990).

22. E. Blackwelder, Geol. Soc. Am. Bull. 42, 865 (1931).

23. Values of $\delta^{18} \mathrm{O}$ from 40,000 to 30,000 years B.P. are generally low, indicating a period in which precipita- tion fell as snow. The lack of pronounced glaciation during this interval is probably the result of relatively high warm-season (May through August) insolation [A. Berger and M. F. Loutre, Quat. Sci. Rev. 10, 297 (1991)].

24. The introduction of glacially derived clay increased lake turbidity, decreasing photosynthetic production of organic carbon. Seasonal ice cover and decreased water temperatures also decreased productivity.

25. Radiocarbon age control for OL90-2 and V23-81 is no better than 500 to 1000 years. Thus, the time between maxima and minima in both records is of the same order as the composite ${ }^{14} \mathrm{C}$ error, implying that North Atlantic lithic events cannot be uniquely matched with advances or retreats of $\mathrm{Si}$ erran glaciers.

26. The lack of correlation between high-frequency events in the lithic and $\delta^{18} \mathrm{O}$ records may derive from the fact that North Atlantic climate variability mainly depended on changes in air temperature (Dansgaard-Oeschger cycles), whereas the hydrologic balance of Owens Lake depended not only on air temperature but also on cloud cover, humidity, and precipitation [L. V. Benson, U.S. Geol. Surv. Water
Resour. Invest. Rep. 86-4148 (1986)]. The poor correlation may also result from the timing of carbonate precipitation. Precipitation is favored by warm water temperature and high concentrations of $\mathrm{Ca}^{2+}$ and $\mathrm{CO}_{3}{ }^{2-}$. These conditions occur in the late autumn when overflow is at a minimum and $\delta^{18} \mathrm{O}$ values are high and not necessarily representative of average overflow conditions.

27. There are about 19 glacial cycles between 52,500 and 23,500 years B.P.; however, some of the older Tahoe advances (for example, $A_{2}$ ) may consist of more than one glacial cycle.

28. We thank J. Andrews, G. Bond, and S. Lehman for their excellent reviews and suggestions. W. C. McClung of Lake Minerals Corporation allowed us access to the coring sites. Support was provided by the U.S. Geological Survey Global Change Program, NSF, and a University of Southern California Faculty Research Innovation Fund grant. The work was performed in part under the auspices of the U.S. Department of Energy by Lawrence Livermore National Laboratory under contract W-7405-ENG-48.

25 April 1996; accepted 12 August 1996 